\title{
Information literacy: Hvad skal man vide for at søge efter information?
}

\author{
Af Jack Andersen
}

\section{Introduktion}

Informationssøgning kan betragtes som en banalitet $i$ betydningen, at det er noget enhver mestrer. Eller det kan betragtes som en problematik, der kan tages seriøst. Vælger man det første, er der vel ikke belæg for at undervise og forske i faget på f.eks. Danmarks Biblioteksskole. Vælger man det andet, medfører det, at man nødvendigvis må gøre sig nogle overvejelser af teoretisk og metodisk karakter, der kan retfærdiggøre og begrunde, hvordan og hvorledes man kan anskue denne problematik. Indenfor et beslægtet område som for eksempel læse- og skriveforskning, betragtes færdigheder i læsning og skrivning ikke som en banalitet eller som uproblematiske. Alle der har gået i skole vil vide, at det ikke er evner, man bare mestrer, men noget man tilegner sig (eller ikke). Ellers ville man netop ikke gå i skole. I det omfang informationssøgning kan forbindes til en tekstuel virksomhed på linie med læsning og skrivning, kan der ikke opretholdes et argument om, at informationssøgning er af uproblematisk karakter. En antagelse bag denne artikel er, at i og med ere og ere mennesker kommer i kontakt med systemer af organiseret viden (som f.eks. Intranet og Internet) i såvel arbejde som hverdagsliv, da bliver færdigheder $\mathrm{i}$ at finde, vurdere og sortere information ligeså centrale som læsning og skrivning. Det medfører, at færdigheder i informationss øgning ikke er forbeholdt professionelle informationss $\varnothing$ gere som f.eks. bibliotekarer. Informationssøgning er en kulturteknik på linie med læsning og skrivning, hvorfor der ikke er langt fra læse- og skrivekompetencer til informationss $\varnothing$ gningskompetencer. Dette medfører yderligere, at ligesom læse- og skrivefærdigheder ikke er naturligt medfødte evner, ligeledes forholder det sig med informationssøgningsfærdigheder. I denne artikel vil jeg derfor anlægge nogle teoretiske betragtninger omkring denne problematik for ad den vej komme med et bidrag til et informeret udgangspunkt for 'information literacy' og informationssøgning.

Begrebet der dækker over færdigheder i, evnen eller kompetencen til kritisk at søge og lokalisere relevant information kaldes ofte for 'information literacy'. Begrebet har over tid haft varierende navne såsom 'bibliographic instruction', 'information literacy' 
og 'information competence'. Jeg vælger her konsekvent at bruge begrebet 'information literacy'. Med inspiration fra den amerikanske skriveforskning ('composition studies'), vil jeg i det følgende behandle begrebet 'information literacy'. Den amerikanske skriveforskning tager udgangspunkt $i$ at det at skrive er en svær disciplin at beherske, hvorfor spørgsmålet om, hvad det er, man skal vide for at kunne forfatte en tekst, spiller en centrale rolle i denne forskning. Jeg vil kredse om spørgsmålet, hvad det er, man skal vide for optimalt at kunne søge efter information. Jeg bruger her 'informationss $\varnothing$ gning' som betegnelse for den aktivitet, der finder sted, når man søger efter information i systemer af organiseret viden (f.eks. biblioteker, arkiver, Internet, håndbøger, bibliografier, kataloger). At betegne informationssøgning på denne led er naturligvis en meget a edt, eller sekundær, måde, idet den sociale arbejdsdeling i samfundet må betragtes som et primært system af organiseret viden. De dokumenter der findes $i$ et elektronisk informationssystem, er produceret af nogen for nogen med henblik på et bestemt formål. De er et produkt af en allerede organiseret praksis. Jeg har derfor til hensigt i det følgende at argumentere for, at viden om informationskilder og søgningen og brugen af dem er forudsat af en indsigt $i$, hvordan viden er socialt organiseret i samfundet. Til dette formål tager jeg afsæt i Jürgen Habermas' offentlighedsteori (Habermas, 1996 [1962]). Denne kan bruges til at analysere, hvordan samfundet er organiseret som en informationssfære. Indledningsvist vil jeg lave nogle betragtninger over 'literacy' og 'information literacy'.

\section{'Literacy' og 'Information literacy'}

Der findes ikke umiddelbart nogen direkte dansk oversættelse af det engelske ord 'literacy'. Generelt bruges ordet om graden af læse- og skrivekompetencer en person måtte besidde. Sådanne kompetencer begrænser sig ikke kun til at kunne beherske grammatik. Sådanne kompetencer påvirker, hvordan et samfund eller en kultur organiserer sig. Den britiske antropolog Jack Goody har i adskillige værker argumenteret for, på hvilken måde literacy indvirker på samfundets organisering (Goody, 1977, 1986, 1987, 2000; Goody \& Watt, 1963). I bogen 'The Logic of Writing and the Organization of Society' (1986) viser Goody for eksempel, hvordan samfundene og deres organisering i Nærorienten og oldtidens Egypten ændrede sig med indførelsen af og brugen af skriften i juridiske, politiske, religiøse og handelsmæssige aktiviteter. Ligeledes præsenterer Nico Besnier i bogen 'Literacy, Emotion, and Authority Reading and Writing on a Polynesian Atoll' (1995) et etnografisk studie af, hvorledes indførelsen og brugen af skriften på den polynesiske $\varnothing$ Nukulalae påvirkede og omformede den sociale organisering på øen. Dette skete som konsekvens af, at nogle mennesker i dette samfund hurtigt tillagde sig læse- og skrivekompetencer og brugte disse i sociale aktiviteter som f.eks. pengespørgsmål, administration, brevskrivning. Som følge af at ikke alle mennesker besidder eller har mulighed for at komme i besiddelse af sådanne kompetencer, medfører dette en bestemt samfundsmæssig organisering: Opdelingen i læse- og skrivekompetente personer og dem der ikke har disse kompetencer. Hvad Goody og Besnier's studier altså påpeger, er, at læse- og skrivefærdigheder ikke blot er tekniske og neutrale færdigheder, men i den grad også sociopolitiske færdigheder forbundet til menneskelig virksomhed. Læse- og skrivefærdigheder organiserer sociale aktiviteter og er på den led knyttet til måden, hvorpå mennesker agerer $\mathrm{i}$ kommunikationssituationer; dvs. hvad mennesker udretter med sproget.

Informationssøgning som en menneskelig aktivitet er naturligvis ikke noget nyt (1). Mennesket har til alle tider søgt information til at underst $\varnothing$ tte dets virksomhed. Jægeren i stenalderen har f.eks. ledt passende steder til at jage dyr med henblik på, at kunne forsyne hans boplads med mad. Man skal dog ikke mange år tilbage $\mathrm{i}$ tiden, før informationssøgning i databaser og andre informationssystemer næsten udelukkende var noget, der foregik i industrien, forskningsverdenen eller biblioteksverdenen. Med udbredelsen af Internettet som informationskilde kan man sige, at det at søge information er blevet en fast ingrediens i det moderne menneskes hverdags- 
aktiviteter. Vi har f.eks. mulighed for at søge efter billetter over Internettet, søge efter madopskrifter, læse og høre nyheder, søge efter information om rejsedestinationer, søge efter faglige dokumenter osv. Dette betyder altså, at en lærd person i det moderne samfund ikke kun er en med læse- og skrivekompetencer, men også med informationssøgningskompetencer, eftersom vi ikke længere nødvendigvis er afhængig af professionelle informationsformidlere til at hjælpe i informationssøgningsaktiviteter.

\section{'Composition studies'}

Jeg vil i det følgende afsnit redegøre for, hvordan man opfatter skriveproblemet i den amerikanske skriveforskning. Dette gør jeg med henblik på at kunne diskutere og analysere, hvad man skal vide for at kunne søge information i systemer af organiseret viden.

I USA dyrkes forskningsområdet 'composition studies'. Dette område har undergået forskellige teoretiske forandringer; fra formalistiske studier over kognitive tilgange til en nu mere sociohistorisk og virksomhedsteoretisk vinkel på skrivning (2). Skriveforskningen i denne tradition fokuserer naturligvis på at gøre studerende bedre til at skrive. Derfor spiller spørgsmålet om og svaret på, hvad man skal vide for at kunne skrive en tekst en afgørende rolle. I 1982 skrev Patricia Bizzell en artikel, hvori hun kritiserede den dengang dominerende kognitive tilgang til skrivning. Hun argumenterede i stedet for en mere socialt orienteret tilgang med udgangspunkt i begrebet 'diskursfællesskab' (3). Bizzell pointerede, med henblik på at hjælpe folk (dvs. primært studerende) i deres skrivevirksomhed: '...we need to explain that their writing takes place within a community, and to explain what the community's conventions are.' (Bizzell, 1982, s. 230). Bizzell peger altså på, at det at skrive finder sted indenfor nogle rammer, der mere eller mindre former og in uerer på det, der skrives. Dette leder én hen til et andet centralt begreb indenfor skriveforskningen: Den retoriske situation. Denne består af elementerne afsender (skribent), formål, modtagere (publikum), emne og kontekst. Forståelsen af den retoriske situation, man som skribent befinder sig i, er af afgørende betydning. Mangel på forståelse af den retoriske situation indebærer, at ens budskab ikke nåede den intenderede målgruppe, fordi budskabet ikke havde nogen effekt på denne. En skribent skal altså ikke kun have en viden om det emne, man fors $\emptyset$ ger at forfatte en tekst om. Man skal altså også have en viden og forståelse af, hvordan man kommunikerer sit budskab til den intenderede målgruppe. Dvs. en viden om og forståelse af, hvordan man mest hensigtsmæssigt formidler sit budskab med mest effekt hos målgruppen. Til dette formål skal man således have, hvad der kaldes 'genreviden'. Man skal være besiddelse af en viden om, hvordan man kommunikerer indenfor et diskursfællesskab; dvs. hvad er normerne med hensyn til vokabular, tekstkomposition, skrivestil m.m. samt, hvad der legitimerer disse.

Begreberne 'diskursfællesskab', 'den retoriske situation' og 'genreviden' hænger altså uløseligt sammen, når man skal skrive en tekst. De udgør den viden en skribent skal være i besiddelse af for hensigtsmæssigt at kunne kommunikere et budskab ud til den intenderede målgruppe. Mangel på denne viden er altså ensbetydende med, at man ikke er i stand til at skrive en tekst, der giver mening for modtagerne. Det er derfor, det er så vigtigt, når Bizzell argumenterer for, at det er afgørende for skribenter, at de indser, at deres skrivevirksomhed finder sted indenfor et fællesskab med udviklede konventioner for skriftlig kommunikation. Senere i artiklen vil jeg analysere begreberne 'diskursfællesskab', 'den retoriske situation' og 'genreviden' i tilknytning til informationssøgningsproblematikken.

Indenfor de senere år har den amerikanske skriveforskning bevæget sig udover at lære studerende akademisk skrivning til at forankre skrivevirksomheden $\mathrm{i}$ et bredere samfundsteoretisk perspektiv. Christian R. Weisser (2002) baserer således sin bog på Habermas' offentlighedsteori for herigennem at åbne op for en forståelse af skriveaktiviteten som en sociopolitisk handling, man som studerende også er involveret i. I næste afsnit vil jeg kort redegøre for 
Habermas' offentlighedsteori med henblik på at argumentere for, hvorledes denne kan anskues som en teori, der forklarer samfundet som en informationssfære. Denne teori anskueliggører, hvordan informationskilder er organiseret i samfundet. Dette medf $\varnothing-$ rer, at viden om informationskilder og søgning og brug af dem forudsættes af en viden om, hvordan viden er socialt organiseret i samfundet.

\section{Jürgen Habermas' offentlighedsteori}

Den tyske filosof og samfundsteoretiker Jürgen Habermas publicerede i 1962 sit ind ydelsesrige værk 'Strukturwandel der Öffentlichkeit' (oversat første gang til engelske i 1989; seneste engelske udgave er fra 1996). Offentlighedsteorien er en samfundsteori, der kan bruges til at forklare, hvorledes forskellige typer af kommunikationsgenrer bliver brugt $\mathrm{i}$ den sociale og ideologiske organisering af forskellige sfærer og områder i samfundet. Dokumenter og deres rolle i samfundet betinger således, hvordan de kan søges efter. I det følgende skal jeg kort beskrive Habermas' offentlighedsteori baseret på 1996-udgaven.

Offentlighedsteorien handler om udviklingen af det moderne borgerlige (kapitalistiske) samfund inddelt i forskellige sfærer. Den beskriver opkomsten og faldet af en kritisk ræsonnerende borgerlig offentlighed. Offentlighedsteorien er en samfundsteori, der betoner forskellige kommunikationsmediers rolle i organiseringen og transformeringen af det moderne samfund, i formeringen af den offentlige mening samt, hvordan de relaterer sig til den kapitalistiske produktionsmåde. På denne led kan offentlighedsteorien også betragtes som en teori om den sociale organisering af viden i samfundet.

Habermas (1996, s. 27) skriver om den borgerlige offentlighedssfære:

"The bourgeois public sphere may be conceived above all as the sphere of private people come together as a public; they soon claimed the public sphere regulated from above against the public authorities themselves, to engage them in a debate over the general rules governing relations in the basically privatized but publicly relevant sphere of commodity exchange and social labor."

Habermas fremhæver her om offentlighedsbegrebet, at det udgøres af private personer, der sammen skaber en offentlighed og at disse selv samme personer kræver ind ydelse på politiske handlinger.

Habermas' beskrivelse af den sociale organisering af samfundet er illustreret i nedenstående figur.

Privatområdet og offentlighedsområdet udgør tilsammen civilsamfundet. Der er en vertikal adskillelse mellem civilsamfundet og staten, fordi førstnævnte i Habermas' model er udviklet i opposition til staten. Om privatområdet og offentlighedsområdet skriver Habermas, at det '...was the authentic "public

\begin{tabular}{|c|c|c|}
\hline Privat område & Offentlighedsområdet & Stat \\
\hline $\begin{array}{l}\text { Socialsfære } \\
\text { - } \quad \text { Produktionen/arbejdet } \\
\text { - Køb og salg }\end{array}$ & $\begin{array}{l}\text { Politisk offentlighed } \\
\text { Politisk debat af so- } \\
\text { cialsfærens produkter/ } \\
\text { genstande }\end{array}$ & $\begin{array}{ll}\text { Statsapparatet } \\
\text { - } & \text { Sikring af retsforhold } \\
\text { - } & \text { Sociale systemer } \\
\text { - } & \text { Kultur-, undervisnings- } \\
\text { og forskningsinstitutio- } \\
\text { ner }\end{array}$ \\
\hline $\begin{array}{l}\text { Privatsfære } \\
\text { - } \quad \text { Familien } \\
\text { - } \quad \text { Følelser, seksualitet m.v. }\end{array}$ & $\begin{array}{l}\text { Kulturel offentlighed } \\
\text { - Debat af kulturprodukter } \\
\text { der vedrører eller udsprin- } \\
\text { ger af privatsfæren }\end{array}$ & \\
\hline
\end{tabular}

(Habermas, 1996, s. 30) 
sphere", for it was a public sphere constituted by private people.' (Habermas, 1996, s. 30). Ifølge Habermas er der udviklet to typer af sfærer indenfor privatområdet: socialsfæren og privatsfæren. I Habermas' udlægning består det nye ikke af de mennesker, der udgør privatområdet. Habermas' grundlæggende argument er, at i løbet af det 18. århundrede udvikledes der imellem privatområdet og staten en offentlighedssfære bestående af en politisk og kulturel offentlighed; altså en offentlighedssfære med en nærmest intermedierende sfære, der forbinder privatområdet og staten. Temaer eller emner der udspringer fra socialsfæren bliver diskuteret i den politiske offentlighed, mens temaer eller emner der har sit udspring fra intimsfæren bliver diskuteret $\mathrm{i}$ den kulturelle offentlighed. På denne led optræder offentlighedssfæren som et organiseringsprincip for den sociale og politiske organisation i samfundet (Habermas, 1996, s. 4).

Forholdet mellem civilsamfundet, dets sfærer og staten er et udtryk for folks aktive produktion, distribution og brug af dokumenter (og medier) til at strukturere forskellige kommunikative praksisser og virksomheder. Dette sætter begrænsninger på, hvad indholdet af disse dokumenter kan være. Offentlighedssfæren er således ikke kun et organiseringsprincip, men også en ind ydelsesrig faktor, hvad angår, hvad der kan og ikke kan kommunikeres.

Offentlighedssfæren udgøres af private personer og er karakteriseret ved forskellige kommunikationsmidler og måder at kommunikere offentligt på. Eksempler på måder og midler til kommunikation er aviserne, tidsskrifter, litteratur, kaffehuse, læseselskaber og klubber. På denne led materialiserer offentlighedssfæren sig altså i en mangfoldighed af kommunikationsgenrer.

Offentlighedsteorien handler på denne led om forholdet mellem civilsamfundet og staten. Den behandler, hvordan disse to domæner kommunikerer med hinanden i samfundet. Opkomsten af en offentlighedssfære skabte en kommunikativ distance mellem civilsamfundet og staten. Dette fremmanede et behov for massekommunikation. Offentlighedssfæren formede et kommunikativt rum for diskussioner af kulturelle, politiske og sociale temaer. Aviserne, kaffehusene og klubberne tjente som offentlige rum for udvekslingen af offentlig mening og kritisk diskussion. De former den diskussion, der finder sted og kan således betragtes som specifikke kommunikationsgenrer udviklet til at tjene kritisk diskussion.

Her er ligger også en del af problemet begravet ifølge Habermas. Aviserne, for eksempel, er også en vare, der ejes af et kapitalistisk foretagende og er på denne måde underlagt den kapitalistiske produktionsmåde. Fordi avisen er en vare, der skal sælges på et marked, er der begrænsninger på, hvordan den skal tjene som et værkt $\varnothing \mathbf{j}$ for en fri udveksling af kritiske meninger og ideer. Denne begrænsning forhindrer en fri demokratisk dialog mellem de involverede parter i en samfundsdiskussion, hvilket en ideel offentlighedssfære forudsætter.

De forskellige sfærer har forskellige kommunikationsbehov og genererer forskellige ideer og opfattelser. Kommunikationen af disse sker således igennem en mangfoldighed af genrer. Statsapparatet vedtager love og producerer lovdokumenter, rapporter og forordninger, der udstikker rammerne for borgerne, så disse kan handle i overensstemmelse med lovene. Dokumenter i den politiske offentlighed er typisk aviser, tidsskrifter og pam etter, der kommunikerer diskussion af politiske emner. Eksempler på dokumenter i den kulturelle offentlighed er aviser, litteratur og tidsskrifter, der kommunikerer kunst, litterære og andre kulturelle emner. Kommunikation i socialsfæren er karakteriseret ved genrer som reklamer, regnskaber, foreningsblade og faglige tidsskrifter, der viser disses forbindelse til arbejde- og produktionssfæren. I privatsfæren er der genrer som f.eks. dagbøger og breve. Alle disse genrer der eksisterer i samfundet organiserer de forskellige sfærers kommunikative aktiviteter. Sfærerne producerer dokumenter med henblik på at agere indenfor og imellem sfærerne. 
Habermas' offentlighedsteori omhandler på denne led forholdet mellem samfundets organiserede kommunikationsstrukturer og genrerne, der er udviklet igennem disse som et udslag af sfærernes og statens kommunikationsbehov. Det er dette, der $\mathrm{g} \varnothing \mathrm{r}$, at offentlighedsteorien kan ses som en teori om den sociale organisering af viden og dokumenter i samfundet, idet den skitserer den sociopolitiske organisering af producenter, formidlere og modtagere af information i samfundet; dvs. den beskriver eksistensen af de kommunikationssystemer der findes $i$ samfundet og deres organisering.

\section{'Information literacy' i offentlighedsteoretisk belysning}

I det følgende vil jeg analysere, hvordan man kan betragte informationss $\varnothing$ gningskompetencer i lyset af begreberne fra den amerikanske skriveforskning og offentlighedsteorien som skitseret ovenfor.

Ved informationssøgning i systemer af organiseret viden er brugere i samspil med dokumenterne, der findes i informationssystemet. Disse dokumenter er skrevet og produceret til mange formål, med mange intentioner og udfra adskillige perspektiver og tilgange. De er skrevet som en del af og som et produkt af menneskelig virksomhed. Fra et retorisk synspunkt kan man sige, at dokumenterne i et informationssystem er et udslag af argumentative aktiviteter. Informationssystemerne indeholder altså argumenter. Informationss $\emptyset$ gning i databaser er altså søgning i argumenter. Dette forhold gør, at informationssøgning er en kompliceret aktivitet, fordi den argumentative praksis, dokumenter er udviklet med henblik på og indenfor, på engang både går tabt og medieres ind i informationssystemet.

Et forhold der er med til at komplicere informationssøgning er den bibliografiske post. Brugere af informationssøgningssystemer møder stadigvæk i mange tilfælde en bibliografisk post. Denne består af mange forskelligartede tekstuelle elementer (f.eks. forfatter, titel, emne, udgiver (4)), der hver for sig har en historie, udfører en bestemt tekstuel opgave og udtryk- ker noget om det dokument, de repræsenterer og på sin vis er med til at materialisere (Andersen, 2002). I informationssøgning kan alle sådanne tekstuelle elementer tjene som potentielle 'subject access points' (se f.eks. Hjørland, 1997, 1998; Hjørland \& Kyllesbech Nielsen, 2001). Brugeren er altså konfronteret med mange potentielle søgemuligheder på grund af disse tekstuelle elementer. Disse er med til at gøre informationssøgning kompliceret i det omfang, man ikke har overblik over, hvornår og hvilke af disse tekstuelle elementer der er mest hensigtsmæssige at bruge, lige netop fordi disse kan tjene forskellige søgefunktioner og forskellige måder at repræsentere et dokument (5). Dette påfører yderligere brugeren af en bibliografisk post med fortolkningsproblemer. Det er ikke åbenlyst, hvordan, hvorfor og hvornår de forskellige tekstuelle elementer relaterer sig til hinanden og andre dokumenter. Der er derfor brug for, hvad jeg vil kalde bibliografisk genreviden. En sådan viden består $\mathrm{i}$, hvordan bibliografiske poster forholder sig til andre dokumenter $\mathrm{i}$ det bibliografiske univers og hvorfor de forskellige tekstuelle elementer overhovedet er tilstede og hvilken aktivitet, de er en del af og understøtter. Bibliografisk genreviden er således ikke kun viden om den enkelte bibliografiske post med dens form og indhold, men også viden om, hvad den bibliografiske post som en tekst afspejler, repræsenterer og udfører; dvs. den organiserede kommunikation der medieres mellem dokument, forfatter, udgiver og bruger.

Brugere interagerer altså med mange lag af organiseret viden som en del af en bredere arbejdsdeling. Studerende, for eksempel, der skal skrive en semesteropgave er afhængig af diverse informationskilder. Nogle af disse findes i deres fags bibliografiske litteratur. Tidsskrifterne der er registreret i fagbibliografierne er ét udtryk for den sociale organisering af viden indenfor et fagområde. Ydermere repræsenterer disse tidsskrifter forskellige teoretiske eller metodiske synspunkter; f.eks. udtrykker et tidsskrift med titlen 'Journal of Experimental...' en præference for eksperimentelle studier, mens et tidsskrift som f.eks. 'History of the Human Sciences' antyder en betoning af historiske studier og dermed også andre metoder 
og teoretiske tilgange. Disse tidsskrifter indeholder også hver for sig et antal forskellige artikler med forskelligt fokus, argumentation og problemstilling. Studerende der udfører informationssøgninger i den bibliografiske litteratur er således i samspil med en mangfoldighed af litteratur (og argumenter) og med mange former for organiseret viden, som de nødvendigvis må besidde en viden om for at kunne være i stand til at skrive deres semesteropgave. De skal altså være i besiddelse af en form for informationskompetence, der dækker over konkrete færdigheder i søgeteknikker og -strategier og konkret kendskab til informationssystemers indre opbygning og disse færdigheders dialektiske forhold til de lag af organiseret viden i samfundet, hvor produktion og brug af dokumenter spiller en afgørende rolle i disse lags sociale virksomhed. Ethvert system af organiseret viden, som f.eks. en database, er udviklet med henblik på at understøtte og mediere den sociale praksis (f.eks. et bibliotek i en organisation eller firma), der danner grundlaget for databasen.

Betydningen af rammerne for søgestrategier og deres afhængighed af og forhold til lagene af organiseret viden er også blevet påpeget af Hjørland \& Kyllesbech Nielsen (2001, s. 286):

'...the more we know about how authors use titles and terminology, how they compose their documents, how they cite other documents, and how they are affected by metatheoretical trends, as well as the more we know about the indexing and abstracting process, the more we know about objective search possibilities.'

Her påpeges søgeteknikker og -strategiers dialektiske forhold til den socialt organiserede produktion og brug af dokumenter og dens konventioner. De objektive søgemuligheder der findes, er ikke kun afhængig af (hvis overhovedet) et givet informationssystems tekniske kapacitet, men er bl.a. betinget af viden om titel- og terminologikonventioner indenfor et givet område, dokumentkomposition, citationsadfærd og metateoretiske trends. Hvis man for eksempel ikke er opmærksom på, at der indenfor et givet domæne er en tendens til at bruge retoriske titler, frem for deskriptive, er en viden om titelkonventioner afgørende for, hvor optimalt man kan udnytte en søgning på titler i et givet informationssystem. I denne udlægning er der ikke langt til, hvad den amerikanske skriveforskning lægger vægt på med begreberne 'diskursfællesskab', 'den retoriske situation' og 'genreviden'. Ligesom en skriveaktivitet finder sted indenfor et diskursfællesskab, gælder dette også for informationssøgere. Deres informationssøgningsaktivitet finder også sted indenfor et diskursfællesskab med bestemte historiske og kulturelt udviklede konventioner. Diskursfællesskaberne og deres konventioner bestemmer den organisering af viden, der bliver foretaget i informationssystemer; dvs. de er med til at udstikke rammerne for, hvad Hjørland \& Kyllesbech Nielsen (2001) ovenfor benævnte som de objektive søgemuligheder. I den konkrete informationssøgningssituation kan man altså sige, at informationss $\varnothing$ geren befinder sig i en form for retorisk situation (6), eftersom informationssøgningsvirksomheden må betragtes som en del af en større kommunikativ aktivitet. Dette indebærer, at informationssøgeren, som 'the informed writer' (jvf. Bazerman, 1995), må vide, hvordan man skal handle indenfor aktiviteter, der er organiseret og formet omkring produktionen og brug af dokumenter. Dette understreger forbindelsen mellem, hvordan viden er socialt organiseret og hvordan den er organiseret $\mathrm{i}$ de informationssystemer, som informationssøgere er i kommunikativ kontakt med.

På denne led kan man altså sige, at hvad man skal vide for at søge information, er forudsat af en indsigt $i$, hvordan dokumenter og viden er socialt organiseret i samfundet. Offentlighedsteorien skitserer, hvordan de dokumenter, der er i samfundet, udspringer af de forskellige sfærer og deres kommunikationsbehov. Dokumenternes funktioner er at vedligeholde, understøtte og organisere social aktiviteter og de opstår netop på grund af behovet for at udtrykke og manifestere disse aktiviteter. I samfundet findes der således adskillige informationskilder som funktion af den sociale organisering. Informationssøgning 
er dermed en aktivitet, der foretages efter, hvordan dokumenter og viden er socialt organiseret i samfundet.

\section{Konklusion}

Ligesom løsningen på skriveproblemer ikke består $i$ at have bedre kuglepenne, skrivemaskiner eller tekstbehandlingsprogrammer til rådighed, men kræver en forståelse for den retoriske situation, man som skribent befinder sig, ligeledes forholder det sig med informationssøgningsproblemer. Løsningen på disse er heller ikke databaser med bedre brugergrænse ader og lign. til sin rådighed. Færdigheder i informationss $\emptyset$ gning er ikke udelukkende af teknisk karakter, som der f.eks. gives udtryk for i lærebøger som Harter (1986) og Large, Tedd \& Hartley (2001). Basalt set består informationssøgningskompetence i en forståelse af, hvordan dokumenterne indeholdt i det informationssystem man anvender, er produceret som et resultat af nogle kommunikative aktiviteter i samfundet. Disse dokumenter argumenterer udfra en mangfoldighed af synspunkter for bestemte intentioner, ideer, teorier eller opfattelser og producerer argumenter og videnspåstande på basis af dette. Dette gør de, fordi det er, hvad de historisk er udviklet til for at kunne understøtte den aktivitet, de tjener. Derfor gælder det, at informationskompetence er en sociopolitisk færdighed, på linie med læse- og skrivekompetencer, knyttet til menneskelig virksomhed. Søgning efter dokumenter i informationssystemer er en kompleks og sociopolitisk aktivitet på linie med læsning og skrivning. Som udtryk for menneskelig virksomhed kan man sige, at søgning efter dokumenter og læsning og skrivning konstituerer hinandens forudsætninger. Den genreviden der er nødvendig i læsning og skrivning gør sig også gældende, når talen falder på informationssøgning i systemer af organiseret viden.

\section{Noter}

1. Informationssøgning som en menneskelig aktivitet kommer også til udtryk første side og første sætning i en lærebog i informationssøgning: 'In- formation Seeking in the Online Age: Principles and Practice' af Large, Tedd \& Hartley (2001, s. 1). Dette virksomhedsorienterede syn på informationssøgning kommer imidlertid overhovedet ikke til udtryk i bogen og dens kapitler. Disse handler i stedet om informationssøgningsadfærd, søgning, browse, grænse ader osv.

2. For en oversigt over dette forskningsområdes historie kan der henvises til artiklen 'Where Did Composition Studies Come From? An Intellectual History' af Nystrand, Greene \& Wiemelt (1993)

3. Begrebet 'diskursfællesskab' bliver i genreteorien defineret som '...den grundlæggende antagelse, at der mellem mennesker eller grupper af mennesker eksisterer fællesskaber, som mere eller mindre kan defineres ud fra diskursive, dvs. kommunikative og sproglige, kriterier. Et sådant diskursfællesskab forudsætter, at de medlemmer, der indgår i fællesskabet, har visse fælles interesser, som de finder det værd at kommunikere med hinanden om, og at de har fælles forståelse af, hvilke mål der er væsentlige.' (Palsbro, 2003, s.116). Hensigtsmæssigheden af begrebet 'diskursfællesskab' har indenfor de senere været diskuteret i den internationale genre- og 'composition'-litteratur (f.eks. MacDonald, 1994; Prior, 1998; Swales, 1990, 1998).

4. I litteraturen bliver dette nogle gange også kaldet for bibliografiske data eller dataelementer; se f.eks. Hagler (1997)

5. Dette er mere eller mindre i overensstemmelse med, hvad Hjørland $(1997,1998)$ har kaldt for "database semantics".

6. Et relateret begrebet i informationssøgningsforskningen har været Wersig's 'problematic situation' (Wersig, 1979). Jeg finder dog ikke dette begreb frugtbart, fordi det har en tendens til at psykologisere situationen. Dette mener jeg, er uhensigtsmæssigt, fordi ved at psykologisere in- 
formationssøgningsproblematikken fjernes fokus fra selve den intellektuelle virksomhed, det er at søge information og dennes relation til og interaktion med lagene af organiseret viden. Begrebet 'den retoriske situation' finder jeg således mere frugtbart, fordi det fastholder en fokus på kommunikationsaktiviteten.

\section{Litteratur}

Andersen, J. (2002). Materiality of Works: The bibliographic record as text. Cataloging and Classification Quarterly, 33(3/4), 39 - 65 (Også trykt i antologien 'Works as Entities for Information Retrieval', redigeret af Richard P. Smiraglia, 2002, 39 - 65. Binghamton, NY. : The Haworth Information Press)

Bazerman, C. (1995). The Informed Writer: Using sources in the disciplines. ( $5^{\text {th }}$ Ed.). Boston : Houghton Mif in Company

Besnier, N. (1995). Literacy, emotion, and authority: Reading and writing on a Polynesian atoll. New York : Cambridge University Press. (Studies in the Social and Cultural Foundations of Language)

Bizzell, P. (1982). Cognition, convention, and certainty: What we need to know about writing. PRE/ TEXT. An Inter-Disciplinary Journal of Rhetoric, 3(3), $213-243$

Goody, J. (1977). The Domestication of the Savage Mind. New York : Cambridge University Press

Goody, J. (1986). The logic of writing and the organization of society. New York : Cambridge University Press

Goody, J. (1987). The interface between the written and the oral. New York : Cambridge University Press

Goody, J. (2000). The power of the written tradition. Washington, D.C. : Smithsonian Institution Press
Goody, J., \& Watt, I. P. (1963). The consequences of literacy. Comparative Studies in Society and History, 5(3), 304 - 345

Habermas, J. (1996). Structural transformation of the public sphere: An inquiry into a category of bourgeois society. Cambridge, MA. : MIT Press

Hagler, R. (1997). The bibliographic record and information technology. (3rd ed.). Chicago : American Library Association

Harter, S. P. (1986). Online information retrieval: Concepts, principles and techniques. San Diego : Academic Press

Hjørland, B. (1997). Information seeking and subject representation: An activity-theoretical approach to information science. Westport, CT : Greenwood Press

Hjørland, B. (1998). Information retrieval, text composition and semantics. Knowledge Organization, 25(1/2), $16-31$

Hjørland, B., \& Kyllesbech Nielsen, L. (2001). Subject access points in electronic retrieval. In: M. E. Williams (Ed.), Annual Review of Information Science and Technology, 35, (s. 249 - 298). Medford, NJ : Information Today

Large, A., Tedd, L. A., \& Hartley, R. J. (2001). Information seeking in the online age: Principles and practice. London : Bowker-Saur

MacDonald, S. P. (1994). Professional academic writing in the humanities and social sciences. Carbondale, ILL. : Southern Illinois University Press

Nystrand, M., Greene, S., \& Wiemelt, J. (1993). Where did composition studies come from? An intellectual history. Written Communication, 10(3), $267-333$ 
Palsbro, L. (2003). Genre - sig tekstens navn. I: E. Halskov Jensen \& J. Anneberg Olesen (Red.), Tekstens univers: En introduktion til tekstvidenskab (s. 97 - 135). Århus : Klim

Prior, P. A. (1998). Writing/disciplinarity: A sociohistoric account of literate activity in the academy. Mahwah, NJ : Lawrence Erlbaum Associates. (The Rhetoric, Knowledge and Society Series)

Swales, J. M. (1990). Genre analysis: English in academic and research settings. New York : Cambridge University Press
Swales, J. M. (1998). Other oors, other voices: A textography of a small university building. Mahwah, NJ : Lawrence Erlbaum Associates

Weisser, C. R. (2002). Moving beyond academic discourse: Composition studies and the public sphere. Carbondale, ILL. : Southern Illinois University Press

Wersig, G. (1979). The problematic situation as a basic concept of information science in the framework of social sciences: A reply to Belkin, N.J. I: Theoretical problems of informatics: New trends in informatics and its terminology. Moscow : VINITI. 